\title{
UNESCO MONOGRAPHS IN THE MAKING OF CULTURAL POLICY
}

\author{
MONOGRAFIAS DA UNESCO NA CRIAÇÃO DA POLÍTICA CULTURAL \\ MONOGRAFÍAS DE LA UNESCO EN LA CREACIÓN DE LA POLÍTICA CULTURAL
}

\begin{abstract}
Between 1969 and 1987, UNESCO published a series of 77 monographs on aspects related to cultural policies of individual countries. Each monograph mobilized cultural policy in very particular ways, by its association with local issues, increasing awareness and communication about issues that formerly had never been grouped together under this label. Based on primary documents concerning the monographs, in this article I show that their production involved the articulation of a network of narratives, repertoires, documents, and publics that contributed to the development of a language of cultural policy, which became a frequent way to talk about and perform public actions related to culture in different places around the globe.
\end{abstract}

KEYWORDS: Cultural policy, public action, UNESCO, public action languages, actor-network theory.

Gabriela Toledo Silva - gatoledosilva@gmail.com

PhD in Public Administration from Fundação Getulio Vargas, Escola de Administração de Empresas de São Paulo - São Paulo - SP, Brazil.

Artigo convidado

DOl: http://dx.doi.org/10.12660/cgpc.v21n70.64441 


\section{Resumo}

De 1969 a 1987, a UNESCO publicou uma série de 77 monografias sobre aspectos relacionados às políticas culturais de diferentes países. As monografias mobilizaram cada política cultural de maneiras muito particulares nos processos de associação com questões locais, aumentando a atenção e a comunicação sobre temas que não eram agrupados anteriormente sob este rótulo. Com base em documentos primários sobre as monografias, mostro que sua produção envolveu a articulação de uma rede de narrativas, repertórios, documentos e públicos que contribuiu para que a linguagem da política cultural se tornasse uma forma frequente de falar sobre e performar ações públicas relacionadas a cultura em diferentes lugares ao redor do mundo.

Palavras-chave: Política cultural, ação pública, UNESCO, linguagens de ação pública, Teoria Ator-Rede.

\section{Resumen}

Desde 1969 hasta 1987, la UNESCO publicó una serie de 77 monografías sobre aspectos relacionados con las políticas culturales de distintos países. Las monografías movilizaran cada política cultural de formas muy particulares por los procesos de asociación con problemas locales y por la aportación de nuevos significados y públicos, aumentando la consciencia e comunicación sobre temas que no eran utilizados anteriormente bajo esta etiqueta. Basándome en documentos primarios acerca de de las monografías, muestro que su producción implicó la articulación de una red de narrativas, repertorios, papeles y públicos que contribuyó al lenguaje de la política cultural hasta convertirse en una forma frecuente de hablar y de realizar acciones públicas relacionadas con la cultura en diferentes lugares alrededor del mundo.

Palabras clave: Política cultural, acción pública, UNESCO, lenguajes de acción pública, teoría ator-rede.

\section{INTRODUCTION}

Although there have been different relations between the state and different conceptions of culture in different historical periods, this paper shows that the coining of a language of "cultural policy" is concomitant with cultural policy-associated actions during the post-World War II period. This language has moved to a more central position over time, particularly between the 1960s and the mid-1980 s.

Over this period, the use of the expression "cultural policy" drifted from being sporadic, incidental, or vague to more central and authoritative arenas where it played key roles. This was a result not only of multiple negotiations concerning its meaning, but also of the languages and audiences the term engaged.

The trajectory of a language is not, therefo- re, an evolutionary line. It is better seen as a narrative of a series of fluctuations that reflect simultaneous transformations of concepts, its places and its publics: translations (Latour, 2005).

Inspired by Actor-Network Theory, I adopt cultural policy as an actant, which is a type of agent, human or non-human, that acts by association with others and gains or loses force when used or disputed by actors interested or affected by them (Latour, 1987; Callon, 1984). Cultural policy, then, is a non-humantype of actant-a language - that circulates and adheres to certain social groups and situations. Its meaning is determined by the effectiveness of its uses and not necessarily by the word's definitions (Bakhtin, 2010). This approach leads to different questions: instead of asking what the language of cultural policy means, this paper focuses on the uses of cultural policy over time in different places. If we take the performativity of language seriously 
(Austin, 1967), it is the history of its uses that creates prevailing or marginal meanings.

In 1967, the United Nations Educational, Scientific and Cultural Organization (UNESCO) produced what became known as the first definition of cultural policy and, since then, the organization has played a central role in promoting cultural policies around the world.

Based on the monographs and letters, memos, and other documents surrounding the production of the 77 monographs commissioned by UNESCO from 1969 until 1987, in this paper I show that the process of their production involved the articulation of a network of narratives, repertoires, papers, and publics that contributed to the development of a language of cultural policy UNESCO'S Work on Culture (1960-1987)

Cultural policy was not on UNESCO's radar until 1966, when the first meeting related to cultural policies was scheduled. This meeting, known as the Roundtable of Monaco, occurred in 1967 and was the first documented effort to shed light on a still opaque question. Its conclusions led UNESCO to develop a programme that would connect different existing narratives under a new form of action oriented towards culture.

During the 14th General Conference, in 1966, the Declaration of Principles of International Cultural Cooperation was approved (UNESCO, 1966, 14C/31). and the Assistant Director-General for Social Sciences, Human Sciences and Culture (ADG/ $\mathrm{SHC}$ ) Mahdi Elmandjra stated the "need for UNESCO to help member states to draw up a cultural policy" (UNESCO, 1966, 14C/92).
Elmandjra's evaluation emphasized:

It was extremely difficult to define what culture was and, in speaking of culture, to precisely know what was meant. (...) If the programme for culture appeared-and would doubtless continue to appear-static and sometimes less coherent than the programmes for other sectors, that might also be due to the fact that in most cases it was reflecting the absence of a cultural policy in Member States. (UNESCO, 1966, 14C/92)

Following such directions, a roundtable of invited experts took place in Monaco in 1967. The objectives of the meeting were to confront governments' perceived problems regarding the elaboration of cultural policies; but most of the discussion ended focusing on the very notion of cultural policy:

La notion de politique culturelle est encore neuve et elle demande á être élucidée tant dans les pays industrialisés où l'action culturelle est discutée et dispersée, que dans les pays nouveaux où des principles d'action efficacies peuvent être mis en place rapidement (Working document of the roundtable, 1967)

Discussants were not sure to what extent it reflected a new demand or a new solution to an old problem or if it even changed anything at all. It was, in some sense, a meta-meeting, in which the validity, pertinence, definition, and scope of cultural policy was subject to collective scrutiny.

A new 10-year (1969-1978) programme launched to help member states "put cultural policies into effect," establishing guidelines, 
principles, methods, and means to assess cultural needs.

UNESCO started to commission a variety of study projects related to the subject. Thematic studies were entrusted to experts and working groups, who often came together to discuss topics such as cultural centers, training of cultural administrators, financing of culture, cultural development, conditions of the artist, and more. The theme of cultural information and statistics became a programme in itself, the departments of culture and statistics engaged in a joint endeavor to develop a cultural thesaurus and international categories for assessing and comparing cultural data. Of the 175 meetings related to cultural development listed for the period from 1967-1989, 42 were devoted to cultural statistics and indicators, 31 to cultural development, 24 to training cultural action professionals and 19 to cultural policies. The number of meetings also increased significantly as time went on: 11 from 1967 until 1969, 53 from 1970 to 1979, and 113 from 1980 to 1989.

The Roundtable of Monaco, with its 35 participants, was a Category VI meeting; it should submit suggestions or advice to UNESCO in a report to the Director-General, who would decide how to use the information. In 1970, The Intergovernmental Conference on Institutional, Administrative and Financial Aspects of Cultural Policies (Venice, August 24 to September 2, 1970), was larger and institutionally stronger: it was a Category II meeting of representative character, that involved 85 member states, two international NGOs, and two foundations. Its conclusions and recommendations had to be followed both by UNESCO and member states after they were approved during the next General Conference (UNESCO Constitution, 1946; Art. IV, § 4). During the '70s, regional intergovernmental encounters were also organized. The first took place in Europe, in Helsinki (1972), and was followed by conferences in Asia (Yogyakarta, 1973), Africa (Accra, 1975) and Latin America (Bogota, 1978). This series of meetings found their culmination in the World Conference on Cultural Policies in Mexico City in 1982 (MONDIACULT), which was attended by 960 participants from 126 states. Other meetings, mostly non-representative, were experts who met to prepare for the intergovernmental meetings.

While the most visible work of UNESCO consists the political regulation of matters concerning its fields of activity, these activities reveal a plural set of strategies and a detailed and complex network of languages and publics. Conventions, recommendations, and declarations are the formal, public, and institutional product of a long chain of procedures involving different and heterogeneous instances of decision and implementation and constitute only one part of UNESCO's work. UNESCO has a variety of methods to carry out its projects: publications, seminars, missions by experts, partnership with international or regional institutes, field studies, surveys, contracts with member states or experts, statistical abstracts, comparative studies, and scholarly meetings, to name a few. For a preliminary study to become a convention or a recommendation, it must be submitted, commented on, detailed, redrafted, and, eventually, accepted, detailed and re-drafted by the Executive Board, the General Conference, the Director-General, the member states, the Director-General again, and again the member states, in this order. If approved, a 
committee of governmental experts and the General Conference make the final decision concerning its adoption (UNESCO, 2014).

The General Conference meets every two years and is the highest decision body of UNESCO. It is at this conference that member states approve programmes, policies, elect members of the Executive Board, and, every four years, the Director-General, who is in charge of the corpus of international civil servants known as the Secretariat. Other groups and organizations also play a key role and have formal ties to the organization: National Commissions, international NGOs, and an "enormous number" of experts and consultants

\section{CONCEPTION AND PRODUCTION OF THE MONOGRAPHS}

The publication project began timidly. While planning the Roundtable of Monaco, the organizers felt the need to inform the discussion with practical examples, so a few National Commissions were asked to produce a brief summary of their countries' actions related to the theme. The organizers considered the possibility of making the pre-conference documents public, but abandoned the idea because they felt the concept of cultural policy needed to be further explored and a broader consensus established. The discussions during the meeting and the recommendations that followed saw these monographs as mandatory points of departure for an international discussion on cultural policies.

These few modest dossiers were transformed into a large-scale publication project. Authors could be national experts, government representatives, or national commis- sion members, but they all wrote in their individual capacity, instead of representing UNESCO. Although no methodologies were defined, UNESCO was in charge of choosing the topics, asking the questions, reviewing the content, and authorizing the publication, as suggested in this guideline:

It is not UNESCO's objective to establish a model cultural policy, but to determine what are the constituent elements of a cultural policy for which UNESCO, as an international organization, can provide assistance of a conceptual or methodological nature. The aim is to obtain, in respect of culture, a body of working data comparable to that collected earlier for the education and science sectors. (Letter sent by UNESCO to Member States, 1967)

While the letter emphasized the author's freedom and restricted the reach of UNESCO's own guidelines, it affirmed the existence of cultural policies; these were understood to have constituent elements and data that could be compared as well as conceptually or methodologically assessed. A more detailed script followed some months later:

1. He [the author] will describe the principles which guide the administrative structure and the methods of financing cultural activities in his country. He will explain which information is needed in this field.

2. He will distinguish between traditional systems for the dissemination of culture (libraries, museums, theatres, etc.) and any new systems which could be proposed, making use of modern technical media (television, cinema, radio, etc.)

3. He will describe the most effective institutions for cultural action recently establi- 
shed of being prepared at present in his country.

4. He will try to define the methods by which the cultural needs of the population could be made known.

5. He will describe the principal training methods of the personal necessary for cultural development.

6. He will, in particular, explain what action is being taken to encourage artistic creation while perceiving its innovating and independent character.

7. He will describe the measures taken or envisaged in his country for drawing up a long-term cultural policy on the following basis: assuming the probable evolution of society during the next 15 years, what are the desirable standards and the possible action? (UNESCO, Minute letter to Member States, 1967)

Despite the openness of the call for submissions, the letter stated that a cultural policy was made up of principles, systems of dissemination, institutions, methods of administration, cultural needs, training methods, encouragement of artistic creation, and long-term aims-or the lack of any of these components. Cultural policies were invested with some degree of technicality, and could be detached from more controversial contexts to become something that experts could study.

The Venice Conference was a turning point for the project. By 1970, the reports were extended; the word limit stretched from 9,000 to 40,000 words. The number of interested readers had grown to such an extent that UNESCO was considering charging for the documents. The preparatory meetings and conferences that took place between 1970 and 1982 became opportunities for both authors of the reports and those involved in other UNESCO studies on cultural policies to meet and discuss their work in different stages, Thus, ideas circulated across projects.

The lack of commonalities between manuscripts and the different profiles of the authors and experiences to be reported made the work of UNESCO harder in order to manage the collective production of a universal language that could convey local accounts of culture. The monographs represent UNESCO's first attempt to produce, organize, centralize, and collectively group as cultural policy potentially comparable information on matters related to different actions. They performed part of a complex dialogue, a communication network in which the language of cultural policy was locally articulated and each local input traveled this network in different ways. This reveals how each author, coming from specific national as well as local realities, translated UNESCO's guidelines to his/her context when identifying actions and problems related to a vague concept called cultural policy.

\section{PERFORMATIVITY OF BUREAUCRATIC COMMUNICATION}

What effect did UNESCO's actions have on the publics engaged in the circulation of cultural policy language? Each action, in its detailed sequence of bureaucratic procedures, triggered a specific response and engagement that reorganized and boosted the language of cultural policy with new repertoires, uses, and meanings. For John Austin (1968) this would be an effect of the ability of words to do things. For Bakhtin, the irreducibility of words to meanings turns the social situation 
of use into its locus of pragmatic effect. For some anthropologists (Latour, 1987; 2005; Riles, 2006), this chain of pragmatic effects is inseparable from the materiality of the support in which words are inscribed and from the habitual and local acts that give sense to the use of such materialities-the documents.

Documents are minimally standardized technologies of communication invested with power and authority within certain institutional contexts-especially those developed inside highly bureaucratic organizations like governments or UNESCO. Documents give form to rights, duties, recognition, control, and regimentation by classifying, identifying, and referencing other documents; they institute subjects and objects of regulation and the practices that confer them authority are knowledge forms distinctive to modern life (Riles, 2006). If we follow this argument, documents and the practices they entail can also accomplish actions: documentary practices are social and performative.

To produce the series of monographs, "Studies," UNESCO resorted to a series of documentary practices: a number of people had to be consulted, the Roundtable of Monaco summarized, the long-term project approved, the publication budget included in the biennial programme, the staff allocated in the management of drafts and, most important, there were questions that had to be formulated and circulated to be answered outside of UNESCO. When asked about cultural policies, monograph authors had to (a) formulate an understanding of what cultural policies were about; (b) identify this understanding with experiences inside or outside of their home country; and (c) justify the exis- tence or absence of this recently-named cultural policy and situate it within local political, social, and economic narratives. The mere postulation of the question activated a need to look at local experiences in a different way. The United States was the first case study published in the collection (Mark, 1969). The author Charles C. Mark had been the first director of the Arts Endowment Office of State and Community Operations and commissioned by the U.S. Congress to study states' arts councils and governmental support for the arts. The United States has historically played a distinct role in cultural policy language. At the time, the author opted to enlarge what was being defined as cultural policy to include the U.S.: his argument was that lack of action is in itself a kind of cultural policy:

The statement "the United States has no official cultural position, either public or private," leaves room for considerable negotiation and examination. . . Lack of action does become, then, a kind of cultural policy. It is negative space, or free space, in language the sculptor uses. While in other issues this lack of ability to adopt a direct position is a handicap, in cultural policy it seems an advantage. By refusing the central government the right to set policy, the states and private sectors are forced to adopt concepts suitable to their aims, resulting in a pluralistic approach. (...) (Mark, 1969, pp. 9-10)

The monograph did not deny cultural policies existed, nor did it exclude the United States from the group of countries willing to discuss or to have cultural policies of their own. In other contexts, U.S. spokespeople adopted a far more severe position in regard 
to cultural policies, and many times denied having of one. In the 1980s, when internal boundaries within the cultural policy narrative were better defined and aligned with ideological positions towards state interference in cultural manifestations, the United States adopted an increasingly strong position defending the limitation of the role of the state and the free circulation of cultural goods and services.

Another country whose position later grew more skeptical towards government interference is the United Kingdom. But by the early 1970s, the British monograph presented competing views on cultural policy. Some, believed that stimulating the arts could bring social benefits and should therefore be the government's responsibility:

A large section of the population is completely indifferent to anything that comes under the general heading of 'culture' and they have every right to stay in that state of non-grace ... The appetite for culture in this country is less voracious than many of us pretend.' " (Green et al, 1970, p. 12)

This idea faced resistance in its core institution. Representatives of the Arts Council expressed disagreement with the need for coordination and a centralized cultural policy:

There is a traditional distaste for such planning in Great Britain. Current Arts Council policy is quite firmly stated. In the Chairman's view: "It is not, I think, possible for the Arts Council to produce a cultural plan for the nation. I think that would be wrong, both politically and socially wrong." The Scottish Chairman, similarly, has said: "It is by arts rather than by means of an overall plan that we should try and make forecasts of what is likely to be possible or desirable. I do not think we have ever made an overall plan, and I very much doubt if it would be very useful if we got one out." [p. 2191] (Green et al, 1970, p. 56)

The monograph pointed out that although there were conflicting understandings of cultural policy, there was at the time a desire to increase the degree of government actions in the arts (they did not use the word culture). The authors expressed disagreement with some of the positions presented and, conversely, supported the conclusions of the Roundtable of Monaco.

The New Zealand monograph presented a completely different answer: instead of justifying or positioning itself as to the existence of cultural policies, their description almost completely passed off the notion. Their title— "The role of culture in leisure time" (the only monograph without "cultural policy" in the title)-already indicates the tone of the contents. The introduction defines the document as a "brief report on those artistic and aesthetic pursuits which have a large following, or which seem to be developing rapidly in public interest and achievement" (Smyth, 1973, p. 2). Throughout the text, the term "cultural policy" appears only once, to declare that it would not be the purpose of that country:

It is not proposed that research will assist towards the formulation of a planned cultural policy which may then be imposed on the nation, but rather that more knowledge about the New Zealander's response to art and culture will bring us closer to a policy which meets his individual needs. (Smyth, 1973, pp. 85-6) 
The monographs written by socialist- and communist-run governments had a significantly different tone. The monograph produced in 1970 by former Czechoslovakia reflected the proposal for reform initiated immediately before the period of "normalization" after the Soviet invasion. The Czech author combined freedom of artistic creation with the idea culture as civilizing, oriented toward socialist cultural values and connected to the idea of an influential, direct, and transversal state across all cultural areas. Culture was, according to the document, the basis of the political system:

The resolution of the Thirteenth Congress (1966) "on urgent questions of the further development of socialist culture," emphasizes that "the socialist cultural revolution is a long-term process. ... In this process, culture in the widest sense-that is, science, art, the culture of the work and life environment, education, cultural, and educational activities-becomes an indispensable part of society." The resolution emphasizes the importance of problems such as "to the people through art" and simultaneously "to art through the people," the entire breadth of the problems of humanistic and aesthetic education which should be connected with problems of education for manual labour. The resolution points out that "the humanism of culture and art in a socialist society cannot be separated from the complex creation of the living environment." (Marek, 1970, pp. 13, 16)

The Czech monograph shows the extremely contradictory character of the discussion regarding governmental action in culture at that moment. The individual's freedom to create was recognized, but culture was subject to regulations, "directives," and "corrections" to align cultural values to political ideology. The author, Miroslav Marek, was at that time an economist at the Ministry of Culture of Czechoslovakia.

In the 1986, UNESCO commissioned other authors to update the previous study on Czechoslovakia, which advocated more clearly for state intervention, reflecting a time when the internal borders between different cultural actions were becoming sharper.

Authors, including the author of the German monograph, often situated cultural policies as the cornerstone of the political regime, as they existed long before UNESCO discussions:

Under the terms of the Constitution of the German Democratic Republic, national socialist culture is one of the bases of socialist society. The German Democratic Republic shall encourage and protect socialist culture in the service of peace, humanism and the development of the socialist community. Thus, in their most general form, are defined the main characteristics of the republic's cultural policy, which forms an integral part of its national policy. (Koch, 1975, p.1)

The monographs enabled authors to construct their own historical narratives. In the case of the Soviet Union, the origin of cultural policies coincided with the socialist revolution: "The foundations of cultural policy in the Soviet state were laid by V. I. Lenin. He stated that, after the triumph of the socialist revolution, 'The task of raising the cultural level is one of the most urgent confronting us"' 
(Zvorkine, 1970). Egypt, Bulgaria, Cuba, and other countries with socialist regimes at that time also placed revolution as the watershed of cultural policies.

Other types of revolution also ended up linked to the adoption of cultural policy, as in Mexico:

...lo que se podría designar como política cultural del Estado empezó a definirse más claramente y a mostrar cambios cada vez más rápidos, al extremarse la crisis de la que sobrevino la Revolución mexicana, es decir, la serie de movimientos político-sociales que, iniciada en 1910, tuvo como algunos de los hitos más representativos de su evolución la Constitución de 1917 y la formación del Partido Nacional Revolucionario en 1928-1929 .... (Martinez, 1977, p. 9)

To associate cultural policy with revolutions means they involve a break of some sort, a non-continuity of political processes. Cultural policy thus performs the key of a "new society" rather than as a motion already underway: "Culture should be an activity directed to the formation of the new man in the new society. (Otero, 1972)". Some countries with military governments in Latin America also described themselves as revolutionary. In Peru's report, cultural policy is placed as a product of revolution and the document makes use of the ambiguity surrounding the language of cultural policy language to appropriate cultural policy as both socialists and liberals did:

The cultural policy of the Peruvian Revolution must find expression in a series of practical achievements based on princi- ples corresponding to the plans for the new society which the Revolution seeks to build. The aim is to bring into being a cultural community which, in the intellectual, scientific, artistic, technical, and other fields, is a faithful reflection of that society and expresses the thought and action of the new Peruvians. (Peru/INC, 1977, p. 12)

Countries liberated from colonizers-often after a process of political confrontation and disruption also insert cultural policies in a narrative of renovation:

The people will, from now on, be in a position to assimilate the most outstanding cultural achievements of mankind, deepen the knowledge of the cultural values of Africa, and work for the dissemination of their own expressions of revolutionary culture. (Revolutionary People's Republic of Guinea, 1979, p. 2)

Cultural policy appeared, in different monographs, as both a future possibility and as a connection with the past. The Indian monograph, for instance, gave a detailed history of the overlap between culture and social life, and explored the different ways cultural development has played an important role. It addressed the current situation of cultural institutions and viewed a possible cultural policy with reservations:

An analysis of these institutions' work and the role of culture in the educational pattern will, perhaps, give us some idea of the difficulty of culling a central cultural policy from these (Vatzyayan, 1972, p. 18)

Canada goes in the same direction, pointing out that their monograph included things re- 
lated to cultural policy but nothing that could properly be defined as cultural policy itself:

It would be misleading to infer that Canada already possesses a comprehensive cultural policy. This is a challenge for the years ahead. (Schafert, 1976, p. 9).

Colombia, along with Argentina, circumscribes the idea of cultural policy with recent movements in the country, closely linking the arguments made in the monograph to international discussions. Later monographs benefited from the accumulation of early monographs, reports, discussions, conferences, and their repercussions:

No more than 40 years ago, the idea of science policy was a bold innovation. Various factors (the war being not the least effective of them) opened up the way for a practice which today claims the attention and the highest budgetary allocations of the most advanced nations. The concept of "cultural policy" is even more of a novelty and it has, then, to bide its time before it can make headway, coin its terminology, devise its instruments and prove its effectiveness... Although it is true that there is no comprehensive formulation of cultural policy as there is in the economic and education sectors, for example, it is equally true that this situation reflects a stage in the development of our country comparable with that of other countries in the region. The effort that the State is now making through Colcultura is in line with a current of world opinion that has succeeded, through the work of international organizations such as UNESCO and its Member States, in defining the role to be assigned to culture within the overall development of a speci- fic community. (Ruiz \& Marulanda, 1977, p. 75)

France, where UNESCO headquarters is located, is a different case. The country has produced two monographs for the series, both conducted by the DEPS (Département des Études de la Prospective et des Statistiques) of the Ministry of Cultural Affairs, created in 1959. Its director, Augustin Girard, was one of the most constant collaborators to UNESCO programmes on cultural policies.

The logic of the French authors centered on the notions of cultural planning based on cultural needs. Sociological research provided readability to the cultural sector and allowed French planners to point out objectives of the coordination grid that would create and regulate cultural supply and demand-following economic reasoning and adapting the economic vocabulary to culture: needs, supply, demand, optimum conditions, measurement-even if "there ought to be a dialectical relationship between supply and demand," as stated below:

Cultural promotion, defined in these terms, fits naturally into French planning. This is first and foremost because its starting point will be the notion of "cultural needs," which it will be sought to quantify, but also because the character of French planning contributes powerfully to creating a harmony between the objectives of cultural promotion and of planning. ..... Subject to this proviso, planning in the cultural domain will be able to marry quality and democracy, while avoiding the snare of a culture that is either official and "state-oriented" or simply esoteric and divorced from real life. It is by starting from what people want, rather 
than from patronage-whether enlightened or not-that a cultural policy can be evolved". (DEPS, 1970, pp. 13-15)

The idea of planning based on quantifiable demands is grounded on that of economic and social development. It is in connection with the economic sphere and in the wake of its rationality that the French monograph proposes the classification of cultural activities by functions similar to economic production functions-as suggested in some UNESCO documents:

On the strength of this analysis, a policy can be devised for each sphere or sector; characterized, on the one hand, by functions (conservation, education, creation, dissemination), and on the other, by the nature of the means engaged (legal status, magnitude, cost, geographical level of government intervention). Fitting each sector into a standardized and rationalized functional model and assessing the way in which the means are used in relation to one or more of these four functions ensures the unity and coherence of the cultural policy. (DEPS, 1970, p. 15)

The language used by the French monograph is very similar to that used by UNESCO. Consultants, experts, and French delegates played key in UNESCO's cultural policies project, providing it with input, research, and ideas. In this case, the response to UNES$\mathrm{CO}$ adheres very closely to its own speech. In addition to presenting positions on and versions of cultural policy, national monographs also addressed the circulation of cultural policy references. The Argentinian document, for example, written in the late 1970s, used a much larger set of informa- tion than the first studies. Conferences and meetings had already taken place and other countries had already published monographs, so Argentina could dialogue with earlier documents and cross-reference other works (Harvey, 1979).

The above examples show how the monographs' authors, all with different relationships to their governments, reacted to UNESCO's initiative when they had considerable freedom to discuss the subject at hand. The appropriation of the term "cultural policy" varies: some authors show mistrust, others demonstrate analysis, reinvention, argumentative cunning, ambiguity, the addition of new meanings, or positioning. Some, like that of New Zealand, did not see the need to include cultural policy. Other monographs, like those of the U.K. and U.S., discussed positions on cultural policy, while others argued that their cultural policies were older and more deeply entrenched than the discussion proposed by UNESCO. Finally, some saw cultural policy as an idea in motion, which might or might not be adopted in their countries.

\section{CONCLUSIONS AND FINAL CONSIDERA- TIONS}

Among the different studies organized and fostered by UNESCO, the editorial project titled the "Studies and Documents On Cultural Policies" series was the longest and had the largest number of issues. Between 1969 and 1987, 77 volumes produced by 66 countries were issued concerning cultural policies. France, Hungary, Indonesia, Cuba, Czechoslovakia, Great Britain, and Yugoslavia produced two issues each: one at the beginning of the 1970s and a revised and updated version sometime in the 1980s. 
Table 1. Country monographs in the "Studies and Documents on Cultural Policies" series

\begin{tabular}{|c|c|c|}
\hline Year & N. & Country \\
\hline 1969 & 1 & United States \\
\hline 1970 & 6 & France, Japan, United Kingdom, Czechoslovakia, Tunisia, USSR \\
\hline 1971 & 2 & Italy, Yugoslavia \\
\hline 1972 & 8 & Bulgaria, Cuba, Egypt, Finland, India, Iran, Nigeria, Poland \\
\hline 1973 & 6 & Indonesia, Israel, New Zealand, Federal Republic of Germany, Senegal, Sri Lanka \\
\hline 1974 & 5 & Philippines, Hungary, Liberia, United Republic of Tanzania \\
\hline 1975 & 7 & $\begin{array}{l}\text { Afghanistan, Ghana, Kenya, German Democratic Republic, United Republic of Camer- } \\
\text { oon, Togo, Zaire }\end{array}$ \\
\hline 1976 & 1 & South Korea \\
\hline 1977 & 10 & $\begin{array}{l}\text { Algeria, Canada, Colombia, Costa Rica, Ecuador, Guyana, Jamaica, Mexico, Peru, } \\
\text { Venezuela }\end{array}$ \\
\hline 1978 & 3 & Honduras, Panama, Soviet Republic of Belarus \\
\hline 1979 & 6 & $\begin{array}{l}\text { Argentina, Bolivia, Cuba, Guinea Republic, Democratic People's Republic of Korea, } \\
\text { Sierra Leone }\end{array}$ \\
\hline 1980 & 2 & Iraq, Yugoslavia \\
\hline 1981 & 8 & $\begin{array}{l}\text { Saudi Arabia, Australia, Austria, France, Guatemala, Jordan, Lebanon, Morocco. } \\
\text { USSR }\end{array}$ \\
\hline 1982 & 5 & Great Britain, Ethiopia, Popular Republic of Mongolia, Sudan, Yemen Arab Republic \\
\hline 1983 & 2 & Nepal, People's Republic of China \\
\hline 1985 & 2 & Indonesia, Socialist Republic of Vietnam \\
\hline 1986 & 1 & Czechoslovakia \\
\hline 1987 & 1 & Hungary \\
\hline TOTAL & 77 & \\
\hline
\end{tabular}

Source: Based on UNESDOC records and the OCLC database.

The collection may be considered a success. Several volumes went out of print quickly and were republished with a bigger print run. Volumes were distributed for free to participants at successive meetings dedicated to cultural policies and to interested readers, who wrote UNESCO asking for cultural policy references. At a period when there were not many other works to reference, these volumes made their way into libraries throughout the world and made UNESCO the major publisher of titles explicitly dedicated to cultural policies until the 1980s. 
Table 2. Number of "cultural policy" titles per type of publisher

\begin{tabular}{|c|c|c|c|c|c|}
\hline & Until 1960 & $\begin{array}{c}1961- \\
1970\end{array}$ & $\begin{array}{c}1971- \\
1980\end{array}$ & $\begin{array}{c}1981- \\
1990\end{array}$ & Total \\
\hline UNESCO & 0 & 27 & 96 & 38 & 161 \\
\hline Governments & 1 & 4 & 30 & 63 & 98 \\
\hline Council of Europe & 1 & 0 & 7 & 9 & 17 \\
\hline Other Publishers & 8 & 10 & 68 & 155 & 241 \\
\hline Total & $\mathbf{1 0}$ & $\mathbf{4 1}$ & $\mathbf{2 0 1}$ & $\mathbf{2 6 5}$ & $\mathbf{5 1 7}$ \\
\hline
\end{tabular}

Source: Based on OCLC records.

In an experimental project by the Online Computer Library Center (OCLC), the largest international community of libraries, records of associated libraries were joined in a single database, opening new possibilities to bibliographic searches. By extracting a collection of titles containing the expression "cultural policy" or "cultural policies" in English, French, Spanish, and Portuguese, it was possible to classify records by country of publication, type of publisher, type of publication, and number of holdings (i.e., the number of libraries which hold at least one issue of that title). Publications were scarce before 1961, but the number increased drastically over the next decades. Of the overall publications of the period, UNESCO was responsible for $31.1 \%$, and in the years between 1961 and 1980 the organization was responsible for more than half of the pub- lished titles. While UNESCO's share dropped in the 1980s, official publications by governments (both national and subnational) doubled when compared to the 1970 s, continuing an ascending trajectory.

Of the 161 titles published by UNESCO, 134 are part of the monograph series and 21 are reports or documents related to various UNESCO conferences on cultural policies. The 55 monographs published in English have from 176 to 393 holdings each, while editions in French range from 19 to 63 holdings. In Brazil, the monographs can be found in most public university libraries. In the records of the U.S. Library of Congress, UNES$\mathrm{CO}$ is responsible for more than half of the volumes addressing cultural policies from 1961 until 1980.

Table 3. Titles containing "cultural policy/ies" in the Library of Congress

\begin{tabular}{|c|c|c|c|c|c|}
\hline & UNESCO & UNESCO $\%$ & OTHERS & OTHERS $\%$ & TOTAL \\
\hline Until 1960 & & $0 \%$ & 1 & $100 \%$ & 1 \\
\hline $\mathbf{1 9 6 1 - 1 9 7 0}$ & 8 & $67 \%$ & 4 & $33 \%$ & 12 \\
\hline $\mathbf{1 9 7 1 - 1 9 8 0}$ & 49 & $59 \%$ & 34 & $41 \%$ & 83 \\
\hline $\mathbf{1 9 8 1 - 1 9 9 0}$ & 21 & $44 \%$ & 27 & $56 \%$ & 48 \\
\hline $\mathbf{1 9 9 1 - 2 0 0 0}$ & 2 & $5 \%$ & 41 & $95 \%$ & 43 \\
\hline $\mathbf{2 0 0 1 - 2 0 1 0}$ & 1 & $1 \%$ & 108 & $99 \%$ & 109 \\
\hline $\mathbf{2 0 1 1 - 2 0 1 5}$ & 0 & $0 \%$ & 63 & $100 \%$ & 63 \\
\hline
\end{tabular}

Source: Based on Library of Congress records. 
The series of publications, comprising three general issues and 77 national monographs, quickly became a major reference. It was a pioneer project that summarized international experiences and organized ideas that were being exchanged in different places. It was legitimated by UNESCO's network of experts and delegates, and its material results traveled farther than the people behind it. But its circulation was not a matter of unidirectional diffusion of the action language of cultural policy. Rather, its production performed a significant part on the process of development of this language: (a) cultural policy was not pre-defined, (b) each step of the process required multiple agreements between disconnected discourses, and (c) the results reflected the performance of the language in its making.

The monographs, as bureaucratic materialities, caused the following:

(1) They assumed the existence of cultural policy and thus made it more real. The guidelines sent to authors already assumed the existence of cultural policy, using the loose concept as a point of departure, but the wide circulation of the collection spread the word that at least 66 countries had some sort of cultural policy or something relevant to say about the topic. We do not know if the volumes were read or the extent to which they influenced public actions, but the level of involvement they generated and their huge presence in libraries indicates that some discussions traveled very far and contributed to local understandings of cultural actions.

(2) The monographs forced the authors-as spokespersons of either their countries or certain groups - to situate themselves inside or outside the cultural policy outlines and to play with these boundaries when their position was ambiguous. If cultural policies did exist, its publics should be gathered and identified. When different actants of the network lightened by this early circulation of cultural policy were provoked, the geography of publics changed according to their involvement. With actions like this series of publications, UNESCO connected publics and provided a map of how they engaged with the early language of cultural policy.

(3) The monographs led to the production of local versions of cultural policy or alternatives to it. Although this paper is limited in evaluating the impact of the monographs in the countries that produced them, their structure and content point to the fact that even when they were signed by individual authors, they were not made in isolation. To some degree they may have triggered discussions with local public bodies, organizations, and groups who held information, data, and other subsidies that constructed national narratives. And when they did not do this in a satisfactory manner, these publics could also join the discussion by disagreeing, once the texts were made public. Such was the case when an association of writers wrote UNESCO complaining about a certain monograph. Local engagement, awareness, and critique could arise at different times of the process and, once published, for an unlimited period of time.

(4) The monographs created temporal narrative markers, producing historical narratives regarding different countries' versions of cultural policy. In some cases, as in Mexico and Cuba's documents, the descriptions of cultural policy fit older events, creating 
a retroactive classification using the newborn expression still being defined. Others, while they failed to identify cultural policies at the time, focused the text on an orientation toward a foreseen future. In the case of Czechoslovakia's first monograph, this future had, at the time of print, already changed. Colombia, on the other hand, described its cultural policy's "stage," referencing the extent to which the country was attempting to align its actions with UNESCO's priorities. The idea that cultural policy could be compared across international borders enabled the consequent ideas that cultural policies could have different stages of maturity in relation to certain parameters-this idea led to notions of progression and regression.

(5) The monographs invested the language of cultural policy with new repertoires. Many of these are technical terms: principles, methods, evaluation, cultural needs, administrative structures, management, planning, financing, the organization of resources, legislation, budgeting, autonomy, decentralization, training, institutional infrastructures, safeguarding, dissemination, cooperation, and other related expressions of action. UNESCO was not the inventor of cultural policy. If we look at earlier uses of cultural policy, though rare, we find they have been used in contexts such as international sections of newspapers and diplomacy books referring broadly to nations' political regimes, often linked to the idea of nationalism. The monographs were an investment in the technicality of cultural policies. UNESCO, while trying to construct a universal mosaic of national particularities, by the very nature of the role it assumed, implied that the ideas of international comparison and the possibility of technical guidance were plausible and de- sirable-making cultural policy more compatible with democracy and as an object of study and research. In the preface of one of the last monographs published, that of Czechoslovakia, this character is made clear:

...the methods of cultural policy (like those of general development policy) have certain common problems; these are largely institutional, administrative and financial in nature, and the need has increasingly been stressed for exchanging experiences and information about them. This series, each issue of which follows as far as possible a similar pattern so as to make comparison easier, is mainly concerned with these technical aspects of cultural policy. (Simek \& Dewetter, 1986, p. 5)

This investment in technicality did not lead to cultural policy language becoming less political. Just the opposite: it made the internal borders and cracks, which were once vague, much easier to describe in greater detail, quality, and complexity.

El conjunto más extenso sobre políticas culturales em español es la colección de libros y fascículos preparados por la UNESCO sobre los países latino-americanos. La casi totalidade de esos textos se limita a describir el organigrama burocrático de los Estados, enumera las instituiciones y sus principales actividades. . Es difícil formarse uma idea de las contradicciones y polémicas que suele implicar el desarrollo de políticas culturales a traves de esos textos demasiado formales y diplomáticos. (Canclini, 1987, p. 16)

Beyond acknowledging the representative nature of the series, this statement, made 
by Nestor Garcia Canclini, suggests that the monographs were read and discussed. When they went out of print, the language they helped to circulate and strengthen would need new forums. This criticism suggests that more in-depth analysis has to be done, and by other people outside formal diplomatic institutions, such as UNESCO, or even governments. Cultural policy was gathering new publics - in John Dewey's understanding of publics - , for its language was increasingly affecting and being appropriated by persons and groups beyond those who previously had been directly engaged. The new repertoires did not float around the globe after being whispered by UNESCO: they were conceived and circulated while embodied in things-i.e., documents and monographs-and people who spoke for and along with others, forming delimited places where heterogeneous groupings of things and people acted together and performed a language specific to cultural policy.

\section{REFERENCES}

Arizpe, L. (2004). The intellectual history of culture and development institutions. In Rao, Vijayendra, and Michael Walton, eds. Culture and public action. Orient Blackswan, pp.163-184.

Austin, J. (1962). How to do things with words. Oxford, Clarendon Press.

Bakhtin, M. M. (2010). Speech genres and other late essays. University of Texas Press.

Callon, M. (1984). Some elements of a sociology of translation: Domestication of the scallops and the fishermen of St Brieuc Bay. The Sociological Review, 32(S1), 196-233.
France, Aspects de la politique culturelle française. Politiques culturelles: Études et documents, 5, 1970.

Canclini, N. (1987). Políticas culturales en América Latina. México, Grijalbo.

Green, M., Wilding, M. Hoggart, \& R.. (1970). Cultural policy in Great Britain. Studies and documents on cultural policies.

Harvey, E. R. (1979). Cultural policy in Argentina. Studies and documents on cultural policies.

Hoggart, R. (1978). An idea and its servants: UNESCO from within. Chatto \& Windus. Londres.

Koch, H. (1975). Cultural policy in the German Democratic Republic. Studies and documents on cultural policies.

Latour, B. (1987). Science in action, how to follow scientists and engineers through society, Harvard University Press, Cambridge.

Latour, B. (2005). Reassembling The SocialAn Introduction To Actor-Network-Theory. Oxford University Press.

Marek, M. (1970). Cultural policy in Czechoslovakia. Studies and documents on cultural policies.

Mark, C. C. (1969). Cultural Policy in the United States. Studies and documents on cultural policies; 2 .

Martínez, E., \& Puig, J., (1977). La Política cultural de México. Políticas culturales: Estu- 
dios y documentos.

Otero, L., \& Martínez Hinojosa, F. (1972). Cultural policy in Cuba. Studies and documents on cultural policies.

Peru/Inc. (1977). Cultural Policy in Peru. Studies and documents on cultural policies.

Revolutionary People's Republic of Guinea (1979). Cultural policy in the Revolutionary People's Republic of Guinea. Studies and documents on cultural policies.

Riles, A. (2006). Introduction. In Riles, A (Ed.) Documents: Artifacts of modern knowledge. University of Michigan Press, Ann Arbor.

Ruiz, J. E., \& Marulanda, V. (1976). La Política cultural en Colombia. Políticas culturales: Estudios y documentos.

Schafer, D. (1976). Paul Aspects of Canadian cultural policy. Studies and documents on cultural policies.

Simek, M., \& Dewetter, J. (1986). Cultural policy in Czechoslovakia. Studies and documents on cultural policies.

Smyth, B. W. (1973). The Role of culture in leisure-time in New Zealand. Studies and documents on cultural policies.

Organização das Nações Unidas para a Educação, a Ciência e a Cultura. (1946). Constitution. Retrieved from http://www.unesco.org/ ulis/en/

Organização das Nações Unidas para a Educação, a Ciência e a Cultura. (1966). 14C/31. General Conference 14th. Principles of in- ternational cultural co-operation. Retrieved from http://www.unesco.org/ulis/en/

Organização das Nações Unidas para a Educação, a Ciência e a Cultura. (1966).14C/92. General Conference 14th. Report of Programme Commission. Retrieved from http:// www.unesco.org/ulis/en/

Organização das Nações Unidas para a Educação, a Ciência e a Cultura. (1967, June 12). [Minute letter to Member States]. UNESCO Archives 307 A 064 (449.49) "67" Table Ronde de MONACO - Décembre 1967 - "L'action et la politique culturelle" Part I

Organização das Nações Unidas para a Educação, a Ciência e a Cultura. (1967, May 5). [Annex I of letter to Member States]. UNESCO Archives 307 A 064 (449.49) "67" Table Ronde de MONACO - Décembre 1967 - "L'action et la politique culturelle" Part I

Organização das Nações Unidas para a Educação, a Ciência e a Cultura. (1968). 15C/5. General Conference 15th. Approved Programme and Budget for 1969-1970. Retrieved from http://www.unesco.org/ulis/en/

Organização das Nações Unidas para a Educação, a Ciência e a Cultura. (1968). 15C/88. Report of the Programme Commission. Retrieved from http://www.unesco.org/ulis/en/

Organização das Nações Unidas para a Educação, a Ciência e a Cultura. (2014). Rules of Procedure concerning recommendations to Member States and international conventions covered by the terms of Article IV, paragraph 4, of the Constitution. Basic Texts. Retrieved from http://www.unesco.org/ ulis/en/ 
Vatsyayan, K. M. (1972). Some aspects of cultural policies in India. Studies and documents on cultural policies.
Zvorykin, A. A. (1970). Cultural policy in the Union of Soviet Socialist Republics. Retrieved from http://unesdoc.unesco.org/ images/0000/000012/001240eo.pdf 